\title{
The Effectiveness of TPM-Kurtilas in Improving The Basic Character of Children in TK Tunas Harapan
}

\author{
Anggita Indah Pratiwi, Aan Listiana, Yeni Rachmawati, Rita Mariyana \\ Department of Early Childhood Education, Universitas Pendidikan Indonesia, Bandung, Indonesia \\ Corresponding e-mail: anggitaindah.pratiwi@ student.upi.edu
}

\begin{abstract}
This study aimed to test the effectiveness of children's basic character development program through the Teaching Pyramid Modelbased on 2013 curriculum (TPM-Kurtilas). This research is part of a series research trials on TPM-Kurtilas which was implemented in Bandung. This research used quantitative approach with pre-experimental design in One-Group pretest-posttest design. The research conducted in Tunas Harapan Kindergarten, Bandung in 2015-2016 academic year with 16 children total samples. The instrument of data collection used questionare of spiritual and social assessment scale with 50 items. Statistical analysis used is paired sample t-test. The analysis result showed that t-count is -5.575 at significance level $0.000(\mathrm{p}<0.05)$. Besides that, the average of post test score $(159,44)$ is higher than pretest $(171,44)$ score. The findings from the research yielded that TPM-Kurtilas is effective in improving children basic character in Tunas Harapan Kindergarten.
\end{abstract}

Keywords: $\quad$ Effectiveness, Children Basic Character, TPM-Kurtilas

\section{INTRODUCTION}

For the last five years, Statistic Data informed us that children and adolescent abuse cases have reached 21.689.987 that spread widely in over 33 provinces and in 202 counties/cities. For about 369 complaints recorded with $25 \%$ of the total complaints are in the educational field as many as 1.480 cases consisting of school violence, student brawls, and educational discrimination (KPAI, 2014; Berita Satu, 2015).

Character education can be one of the efforts to prevent children's abuse. In the long term, character education serves to direct the children into positive behavior whether for academic skill or even for children's daily behaviour (Silitonga, A.S., et.al, 2014; Izzaty, R.E., 2012; Pala, A., 2011; Marvin, 2002). One of the effective and appropriate place to create children's good character is in early childhood education (PAUD) (Rosmiati, A., 2014;

Mulyatiningsih, E., 2010). Early childhood is a time when individual basic personality formed and a sensitive period in which physical and psychological functions got mature in respond to a series of stimulation given by its surroundings (Montessori in Sujiono, 2009; Solehuddin, M., 2000). Benning, et.al (2003) found that the school which implemented character education got higher academic score in contrast to the condition before the implementation. The importance of character education is also strengthened by a clear legislation basis in the Act No.20 of 2003 the national education article 3:

\footnotetext{
"National education serves to develop the ability and character development and civilization of nation's dignity in the context of the intellectual life of the nation which aimed at developing student's potentials to become a man of faith and devoted to the Almighty God, noble, healthy, knowledgeable, skilled, creative, independent, and become responsible and democratic citizens".
}

But in reality the implementation of character education in early childhood is still very low (Olim, A. 2010; Humaida, 2013; Ratnasari, 2015). One of contributing factors is due to the lack of ability and teacher's knowledge in developing and integrating the aspects of character education. Besides that, akhlak and morality learning tend to be given in just 
a kind of transferring knowledge and comprehension, ignoring habituation which is applicable in everyday life (Muhtadi, A., 2010; Nurchotimah, 2013; Setiawan, 2013; Wardani, K., 2010; Wiyono, H., 2012; Nata, A., 2013).

TPM-Kurtilas (Listiana \& Rachmawati, 2016) is one of the teaching models that can enhance teacher's understanding on the implementation of character development in kindergarten. TPMKurtilas is an adaptive and modified model from Lise Fox (2003) Teaching Pyramid Model that is aligned with 2013 curriculum as a basic reference for the national curriculum. TPM-Kurtilas concept used in this research can be described as follows:

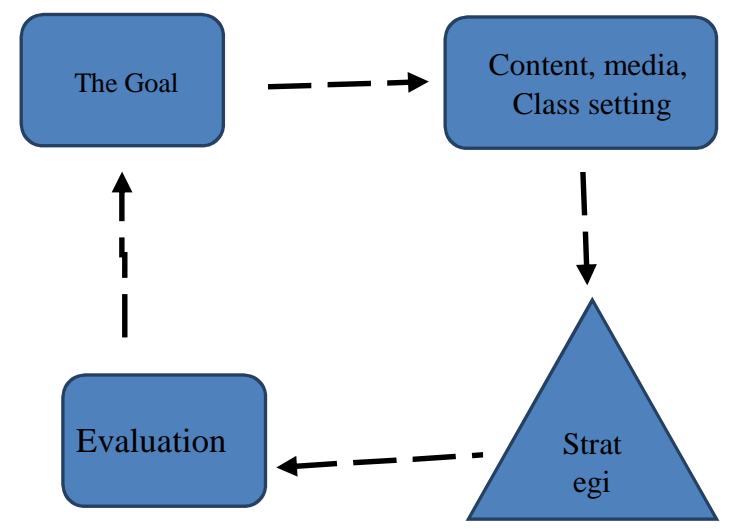

Figure 1. Model TPM -Kurtilas (Listiana \& Rachmawati, 2016)

Previous studies that have been conducted related to TPM itself include research on TPM applied to the class under the age of three years by Branson, D., \& Demchak, M. (2010). Besides the TPM in supporting the formation of social competence and prevent challenging behavior in AUD by Fox, L., et al (2003). Next Fox, L \& Lentini R.H (2006) examines the TPM in teaching social and emotional skills of children. Hemmeter, M.L., et al. (2006) investigated the TPM function in addition to helping build children's social-emotional foundation can also help children in preparing the start of elementary school.

Thus, this article is part of trial series of basic character development model for children through TPM-Kurtilas. The research within the scope of TPM-Kurtilas trials that have been implemented is including the adaptation of TPM-Kurtilas in character development for early childhood by Listiana \& Rachmawati (2016) as the initial research that underlied subsequent studies. Another research that has been done is teacher's perspective on the implementation model by Rachmawati, Y (2016). In addition, the teachers also asked about the impact of behavior changing as a whole or partial behavior of children's discipline and manner as a result from this implementation (Maryadi, B., Listiana, A., Puspadewi, D., \& Tsani, A.N., 2016).

Meanwhile, this article will describe the effectiveness of TPM-Kurtilas Implementation as a part of the research series evaluation. The data of this research will be used as an input or consideration for TPM-Kurtilas development.

\section{METHOD}

This research method uses a quantitative approach and uses pre-Experimental Design with One-Group pretest-posttest design. The method used to test the effectiveness of TPM-Kurtilas in improving children's basic character. There are two variables in this study, TPM-Kurtilas as independent variable and children's basic character as dependent variable. One-group pretest-posttest design is formulated in the following figure:

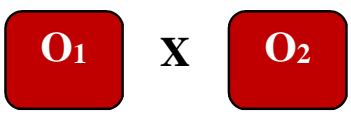

Figure 2. Model One-Group pretest-posttest Design

Note:

$\mathrm{O}_{1}=$ Pretest Score of social and spiritual attitude before program implementation.

$\mathrm{O}_{2}=$ Posttest Score of Social and spiritual attitude after program implementation.

$\mathrm{X}=$ Actions such as the implementation of TPMKurtilas program.

This research took place in TK Tunas Harapan Bandung Academic Year 2015-2016. The test held in Class A with 16 children: 9 boys and 7 girls. The collection data technique used Likert scale questionnaire about social and spiritual assessment consist of 50 items instrument test which is made deliberately in dealing with the evaluation of TPMKurtilas program. The instrument itself is developed by Listiana, et.al. In the year 2015. The technique of data analysis used t-test (paired sample t-test).

1) $\mathrm{H}_{0}: \mathrm{D} \neq 0$ (There is no significant difference in the result of children's basic character development through TPM-Kurtilas in Tunas Harapan Kindergarten).

2) $\mathrm{H}_{\mathrm{a}}: \mathrm{D}=0$ (There is significant difference in the result of children's basic character development through TPM-Kurtilas in Tunas Harapan Kindergarten). 


\section{RESULTS AND DISCUSSION}

Based on the data analysis showed there is significant difference between pretest and posttest. The post-test score is higher than the pre-test score $(171,44>159,44)$. It concludes that TPM-Kurtilas is effective in improving children basic character in Tunas Harapan Kindergarten.

Table 1. Test results-t (paired sample t-test)

\begin{tabular}{llcc}
\hline Test & Mean & Sig. $(\mathrm{p})$ & t-score \\
\hline Pretest & 159,44 & 0,000 & $-5,575$ \\
Posttest & 171,44 & $(\mathrm{p}<0,05)$ & \\
\hline
\end{tabular}

From the analysis above TPM-Kurtilas is effective in improving children's basic character for certain reasons, including:

1) The principles and the stages of TPMKurtilas are in line with the implementation of character education.

TPM-Kurtilas program has certain principles and stages that in line with the implementation process of character education that must be done systematically, sustainable, the strategy usage including knowledge, habituation, and direct practice. Seknun, M. (2014); Setiawan, D. (2013); Nurchotimah, S. (2013); Stiles (in Hidayatullah, 2010) stated that the implementation of character education must achieve the goals and objectives of the program in a way of systematic, sustainable and integrative. Meanwhile the processing stages of character education are 1) knowing the good means transferring the knowledge (Cognitive), 2) building feeling and loving the good (Affective), 3) acting the good means the action (Psychomotoric) then do it in daily life.

The program is designed in a systematic, sustainable, integrative, having certain stages to achieve the goals in order to reach its qualified learning (Hamalik, 2003; Idi, A (2007). Seknun (2014) stated that lesson plan and strategy which previously formulated starting from instructional objectives, materials, methods, procedures, time estimates, assessment, and evaluation tools to make the program implemented in systematic, sustainable, and integrative would make the goals achieved easily.

Moreover, the process of TPM-Kurtilas has procedural steps or separable process that is easier for children to understand the rules, and the values given so that appears the positive effect in changing children behavior as polite, neat, caring, sharing, orderly, organized, and discipline (Rachmawati, 2016; Maryadi, 2016).

2) TPM-Kurtilas is also suitable with the principles of teaching and learning process in early childhood education and with considerable components in the implementation of character education.

TPM-Kurtilas is suitable with the principles of learning process in early childhood education which is oriented in children development, child-centred, character's values development, democratises life skill and supported media (Permendikbud RI, Number 146, 2014). Whereas the components that need to be considered in the implementation of character education in schools in line with TPMKurtilas is in creating a comfortable and pleasant environment, the availability of competent and characterized teachers, the availability of teaching aids which characterized and supportive basis, and cooperative approach that entailed between schools and parents (Sugiyanti, A., 2015).

The content of TPM-Kurtilas includes the setting of learning environment (classroom) and a positive relationship between teachers and children. This content is in line with the children learning processes and components that need to be considered in implementing the character education at schools (Sugiyanti, A. (2015); Permendikbud, 2014). Those Two activities above are crucial components in helping to address children's behavior problems (Hemmeter, M.L., et.al. (2006); Fox, et.al. (2003); Pianta, et.al. (2002); Hunter, et.al. (2009); Curtis, et.al. In Hamalik (2008); 2013 early childhood curriculum, 2014).

TPM-Kurtilas also contained the teaching's oriented to character's values basis (Social spiritual) and life skill (Harjusola, et.al.,(2012); Landy, 2002; Listiana, et.al., 2015; Kirschenbaum, 2000; Golemen, 2001; Permendikbud, 2014). Moreover, TPM-Kurtilas also related to children's learning principles and components of character education implementation. The learning efforts to deal with challenging behavior must be supported by the available media and character basis, such as poster, storytelling, positive behavior's video (Zaman, B. \& Eliyawati, C. (2010); Listiana, et.al. (2015) in order this teaching process is contextualized and meaningful. Besides supported by the media, the teachers also have to be competent and characterized (Fox, et.al.,2009) in cooperation between schools and parents in relation to maintain this positive 
behavior taught also at home so the objectives of TPM-Kurtilas achieved successfully.

\section{CONCLUSIONS}

Based on the test and discussion above, it can be concluded that TPM-Kurtilas program is effective in improving children's basic character in Tunas Harapan Kindergarten, Bandung. It's reasonable because the program has certain principles, stages, and suitable component with the implementation process of character education and with the children's principles of teaching and learning. The principles and stages conduct in a systematic, sustainable, the strategy conducted also based on the knowledge, habituation, and direct practice. Meanwhile, the component and the principles acquired is including the setting of learning environment, positive relationship with the teachers, teaching-oriented and based on character values.

However, internal validity in this study is still low. The reason is that the researcher did not control the extraneous variables that will affect the increase of children's basic character. As well as external validity is limited due to the intervention was only given for 16 children, so the results of this study only apply for those children.

The suggestions below are dedicated for:

1) The next researcher has to do a more in depth study related to the effectiveness of TPMKurtilas in improving children's basic character at school in different level or based on its type of kindergarten in order represented the results in general whether TPM-Kurtilas is effective in improving children's basic character across all locations and existing types of kindergarten

2) The next researcher also can research its effectiveness based on the gender, age or class, children's background (from various social economic level).

The next researcher can conduct the research based on representative samples so this research is not only applied for small/minimum sample.

\section{REFERENCES}

Benning, dkk. (2003). The Relationship of Character Education Implementation and Academik Achievment in Elementary Schools.Journal of Research in Character, Vol. 1 No. 1.

Berita Satu (2015). 667 Kasus Kekerasan Anak Terdjadi Di Jakarta. Tersedia: [Online]: http://www.beritasatu.com/ terbit Selasa, 22

Desember 2015 [06 Agustus 2016]

Branson, D. \& Demchak, M. (2010). Toddler teachers' use of teaching pyramid practices. Topics in Early Childhood Special Education.

Eliyawati, C., Zaman, B. (2010). Media pembelajaran anak usia dini. Bahan ajar: Pendidikan profesi guru (PPG). Bandung: PGPAUD UPI

Fox, L. G. Dunlap, M.L. Hemmeter, G. E. Joseph, \& P.S. Strain. (2003). The Teaching Pyramid: A Model for Supporting social competence and preventing challenging behavior in young children. Young Children 58 (4).

Fox, L., \& Hemmeter, M. L. (2009).A program-wide model for supporting social emotional development and addressing challenging behavior in early childhood settings. In W. Sailor, G. Dunlap, G. Sugai, \& R. Horner (Eds.), Handbook of positive behavior support (pp. 177-202.). New York, NY: Springer.

Fox, L., \& Lentini, R. H. (2006)." You Got It!" Teaching Social and Emotional Skills. YC Young Children, 61(6), 36.

Goleman, D. (2001). Kecerdasan Emosional (terjemahan Hermaya T). Jakarta: Gramedia Pustaka Utama.

Hamalik, O. (2003). Pendekatan baru strategi belajar mengajar berdasarkan CBSA. Bandung: Sinar Baru Algesindo

Hamalik, O. (2008). Perencanaan pembelajaran berdasarkan pendekatan sistem.Cet. VII. Jakarta: Bumi Akasara.

Harjusola-Webb, S., Parke Hubbell, S., \& Bedesem, P. (2012). Increasing prosocial behaviors of young children with disabilities in inclusive classrooms using a combination of peermediated intervention and social narratives.Beyond Behavior, 21(2), 29-36.

Hemmeter, M. L., Ostrosky, M., Fox., L (2006). Social and emotional foundations for early learning: A conceptual model for intervention. School Psychology Review, 35(4), hlm. 583601

Hidayatullah, M.F. (2010). Pendidikan Karakter: Membangun Peradaban Bangsa. Surakarta: Yuma Pustaka

Humaida, C. (2013). Pendidikan karakter tingkat TK di Kabupaten Ponorogo tahun ajaran 2012/2013.Ponorogo: Universitas Muhammadiyah Ponorogo.

Hunter, A., Hemmeter, M. L. (2009). Adressing Challenging Behavior in Infants and Toddlers. 
The Center on The Social and Emotional Foundation for Early Learning. Zero To Three.

Idi, A. (2007). Pengembangan kurikulum teori dan praktek. Yogyakarta: Ar Ruz Media

Izzaty, R. E. (2012). Pentingnya Pendidikan Karakter Pada Anak Usia Dini : Sudut Pandang Psikologi Perkembangan Anak. Tersedia [Online]: http://staff.uny.ac.id/ [06 Agustus 2016]

Kirschenbaum, Howard. (2000).'From Values Clarification to Character Education: A Personal Journey." The Journal of Humanistic Counseling, Education and Development. Vol. 39, No. 1, September, pp. 4-20.1

Komnas Perlindungan Anak Indonesia.(2014). Kasus Bullying dan Pendidikan Karakter. Tersedia [Online]: http://www.kpai.go.id/berita/kpai-kasusbullying-dan-pendidikan-karakter/ [06 Agustus 2016]

Landy, S. (2002).Pathways to Competence: Encouraging Healthy Social and Emotional Development in Young Children. Baltimore: Brookes.

Listiana, A., Rachmawati, Y. (2016). Pengembangan Model TPM-Kurtilas: Adaptasi Teaching Pyramid Model dalam Kurikulum 2013 Guna Pengembangan Karakter Anak Usia Dini. Bandung: PGPAUD UPI

Listiana, dkk. (2015). Pedoman Umum: Program Pengembangan Karakter Dasar Anak melalui Teaching Pyramid Model berdasarkan Kurikulum 2013. Bandung: Universitas Pendidikan Indonesia

Marvin W. B. (2002). Science of Character Education, William Damon (ed). Bringing in a New Era in Character Education. California: Hoover Institution Press.

Maryadi, B., Listiana, A. (2016). Penerapan TPMKurtilas terhadap perubahan perilaku anak.Bandung: PGPAUD UPI

Muhtadi, A. (2010). Strategi Mengimplementasikan Pendidikan Budi Pekerti Yang Efektif Di Sekolah.Dinamika Pendidikan No.01/Th.XVII/MEI

Mulyatiningsih, E. (2010). Pembelajaran Aktif, Kreatif, Inovatif, Efektif dan Menyenangkan (PAIKEM). Depok : DI P4TK Bisnis dan Pariwisata.

Nata, A. (2013). Revitalisasi pendidikan karakter untuk mencetak generasi unggul.Jurnal Didaktika Religia, Vol. 1 No. 1

Nurchotimah, S. (2013).Implementasi kurikulum pendidikan berkarakter di sekolah.Seminar
Internasional evaluasi pendidikan (SNEP) I Th. 2013

Olim, A.(2010). Mencari metode pendidikan karakter untuk PAUD : Belajar berbasis layanan (service learning). Proceedings of the 4th international conference on teacher education: join conference UPI \& UPSI

Pala, A. (2011). The Need For Character Education. International Journal Of Social Sciences And Humanity Studies. Vol 3, no 2, 2011

Peraturan Mentri Pendidikan dan Kebudayaan Republik Indonesia No. 146 tahun 2014 tentang Kurikulum 2013 PAUD.

Pianta R, Burchinal M, Peisner-Feinberg E, Howes C. (2002). Development of academic skills from preschool through second grade: Family and classroom predictors of developmental trajectories. Journal of School Psychology, 40, hlm. 415-436.

Puspadewi, D., Listiana, A. (2016). Profil kedisiplinan anak TK Yayasan Amal Keluarga setelah diterapkan program pengembangan karakter dasar TPM-Kurtilas.Bandung: PGPAUD UPI

Rachmawati, Y. (2016). Pandangan guru terhadap implementasi Program TPM-Kurtilas di TK Bunda Balita, Kotamadya Bandung.Bandung: PGPAUD UPI

Ratnasari, D. (2015). Korelasi hasil penerapan pendidikan karakter dan standar tingkat pencapaian perkembangan anak dikelompok bermain batik sidoarjo.Journal Plus Unesa, Vol. 4 No.1

Rosmiati, A. (2014). Teknik Stimulasi dalam Pendidikan Karakter Anak Usia Dini melalui Lirik Lagu Dolanan. Jurnal Resital Vol.15 No. 1 Juni hlm:71-82

Seknun, M.Y. (2014). Telaah kritis terhadap perencanaan dalam proses pembelajaran. Lentera Pendidikan, Vol. 17 No.1 Juni: 80-91

Setiawan, D. (2013). Peran Pendidikan Karakter dalam Mengembangkan Kecerdasan Moral. Jurnal Pendidikan Karakter, Th III No. 1 Februari

Sholehudin, M. (2000).Konsep Dasar Pendidikan Prasekolah. Bandung: Fakultas Ilmu Pendidikan Indonesia

Silitonga, A.S dkk. (2014). Pengelolaan kegiatan bimbingan konseling untuk pembentukan karakter siswa SD . Jurnal Manajemen pendidikan Vol.9 No.1 Januari, hlm: 28-39

Sugiyanti, A. (2015). Pendidikan Karakter untuk AUD. Tersedia [Online]: 
http://paudjateng.xahzgs.com/[22 agustus

$$
\text { 2016] }
$$

Sujiono, Y.N. (2009). Konsep Dasar Pendidikan Anak Usia Dini. Jakarta: PT Indeks

Tsani, N.A., Listiana, A. (2016). Profil sikap sopan santun anak TK Bunda Balita setelah diterapkan program pengembangan karakter dasar TPM-Kurtilas. Bandung: PGPAUD UPI

Undang-undang No. 20 Tahun 2003 tentang Sistem Pendidikan Nasional

Wardani, K. (2010). Peran guru dalam pendidikan karakter menurut konsep pendidikan ki hadjar dewantara.Proceedings of the 4th Internatonal Conference on teacher education: Join Conference UPI \& UPSI.

Wiyono, H.( 2012). Pendidikan karakter dalam bingkai pembelajaran di sekolah.Jurnal Ilmiah CIVIS, Vol II No.2 Juli. 